UNITED NATIONS

UNIVERSITY

UNU-WIDER

WIDER Working Paper 2016/59

Is feed-in-tariff policy effective for increasing deployment of renewable energy in Indonesia?

Dewi Yuliani*

May 2016 
Abstract: To accelerate the deployment of renewable energy technologies and to secure the electricity supply, the Government of Indonesia has issued several feed-in-tariff regulations for various renewable energy sources, which were previously predominated by pilot projects using government funding. The feed-in tariff is a policy instrument that has been successfully applied in many other countries to support renewable electricity, and it is known for its simplicity in implementation. This study undertakes exploratory research to evaluate how the policy works in Indonesia, not only as stated in official reports, but also in the field. The study's results show that while the policy triggers investment interest in renewable power plants, there are many obstacles encountered at the deployment stage due to imperfections in the feed-in-tariff policy package and some non-cost factors. In addition, several unanticipated side effects were identified at the local level as a consequence of the upturn in investment interest. The study indicates that the transition to cleaner energy is much more challenging for developing countries such as Indonesia.

Keywords: feed-in-tariff policy, renewable energy, deployment

JEL classification: $\mathrm{O} 13$, Q43

Acknowledgements: This research was made possible by UNU-WIDER through the project on 'Political Economy of Clean Energy Transitions'. The researcher would like to thank UNU-WIDER for the opportunity to conduct the research, and to meet and network with other researchers.

* Independent Researcher, Indonesia; deyul.2013@gmail.com.

This study has been prepared within the UNU-WIDER project on 'The Political Economy of Clean Energy Transitions'.

Copyright (C) UNU-WIDER 2016

Information and requests: publications@wider.unu.edu

ISSN 1798-7237 ISBN 978-92-9256-102-4

Typescript prepared by Lesley Ellen.

The United Nations University World Institute for Development Economics Research provides economic analysis and policy advice with the aim of promoting sustainable and equitable development. The Institute began operations in 1985 in Helsinki, Finland, as the first research and training centre of the United Nations University. Today it is a unique blend of think tank, research institute, and UN agency_providing a range of services from policy advice to governments as well as freely available original research.

The Institute is funded through income from an endowment fund with additional contributions to its work programme from Denmark, Finland, Sweden, and the United Kingdom.

Katajanokanlaituri 6 B, 00160 Helsinki, Finland

The views expressed in this paper are those of the author(s), and do not necessarily reflect the views of the Institute or the United Nations University, nor the programme/project donors. 


\section{List of Abbreviations:}

$\begin{array}{ll}\text { GOI } & \text { Government of Indonesia } \\ \text { MEMR } & \text { Ministry of Energy and Mineral Resources } \\ \text { RE } & \text { Renewable energy } \\ \text { FIT } & \text { Feed-in-Tariff } \\ \text { MHP } & \text { Mini/Micro Hydropower } \\ \text { PPA } & \text { Power Purchasing Agreement } \\ \text { SEC } & \text { State-owned Electricity Company (Indonesia's PLN) } \\ \text { DGNREEC } & \text { Directorate General of New Renewable Energy and Energy Conservation } \\ \text { DGE } & \text { Directorate General of Electricity }\end{array}$

\section{Introduction}

Indonesia is an archipelago rich in renewable energy resources including geothermal, hydro, biomass, solar, and wind energy. Due to its location in the 'Ring of Fire', geothermal energy is its main potential source of renewable energy, amounting to 29 GW-40 per cent of the world's total. Of the total potential, up till now only 1,340 MW (less than 5 per cent) has been installed for electricity generation, with another 1,500 MW at various stages of development (DGNREEC 2015). Hydropower is another major source of potential in Indonesia and is estimated to be around 75,000 MW. At present, some 6,000 MW has been installed as large Hydro Electric Power, mostly in Java. Included in this category is small hydro (up to $10 \mathrm{MW}$ ). 217.16 MW of small hydropower plant has been installed in 2015, a large portion of which is used not for profit but for electrifying remote areas (DGNREEC 2015).

For a country on the equator, solar energy is considered the most under-utilized source of energy in Indonesia. Only around $71 \mathrm{MW}$ is installed but mostly belongs to the state-owned electricity company (SEC or Indonesia's PLN) for electrifying remote islands in the eastern parts of Indonesia. At present, the imported amount of solar photovoltaics (PV) is still considerably high, so the Government of Indonesia (GOI) has attempted to boost the local production of PV systems and encourage investors to build PV manufacturers. As an agricultural country, biomass is the other major potential source of Indonesia's renewable energy. This is thought to have a potential 32,000 MW, of which 1,740 MW is planned to be installed in the near future (DGNREEC 2015). Biomass sources include palm oil, cassava, sugar cane, etc., which can be the source of bioethanol and biofuel production.

Despite this abundant potential, the development of renewable energy in Indonesia still faces a hard battle, mostly because of the long legacy of the government's energy subsidies for fossil fuels. According to the Ministry of Energy and Mineral Resources (MEMR), Indonesia's energy demand has been increasing faster than its economic development growth, which amounted to 7 per cent in 2014 (DGNREEC 2014). This demand is currently met largely by fossil fuels, which in turn bleeds the country's finances as Indonesia has become a net importer of both crude oil and refined products since 2004. 
As a response to the increasing demand for energy and for cleaner energy due to climate issues, in January 2014 The National Energy Policy was adopted by the House of Representatives in the form of Government Regulation No 79/2014 (Government of Indonesia 2014), in which the GOI projected that renewable sources would supply at least 23 per cent of Indonesia's energy needs in 2025. The GOI is also committed to reducing greenhouse gas emissions by 26 per cent by 2020 to combat global climate change (MEMR 2015).

Many efforts have been undertaken to increase the deployment of renewable energy, especially to support the increasing electricity demand. These include: obligating the SEC to buy generated electricity from small-scale producers, prioritizing the use of RE, tax incentives, tax holidays for exported equipment, and simplifying the procedure for licences. Lastly, since around 2010 the GOI has implemented its feed-in-tariff (FIT) policy in order to encourage the private sector to develop renewable electricity. The FIT policy ensures that developers get a relatively fair price for electricity generation from renewable energy resources, which are now being used widely in many countries.

This study undertakes exploratory research that aims to evaluate whether the implementation of the FIT policy is effective for the purpose of increasing deployment of renewable energy in Indonesia. A number of official documents and supporting policies set out the plans for renewable energy development in Indonesia. However, no critical study has been carried out into the real outcome of policy implementation in the field. Data analysis is expected to show whether the FIT policy is sufficient, and if not, what are the reasons for this and what can be done to improve it.

This paper is organized as follows. After the introduction, which describes Indonesia's renewable energy situation and outlines the purpose of the study, Section 2 briefly reviews the FIT policy, its principles, case studies, and barriers to implementation. Section 3 outlines the methodology used for data collection and the locations covered by the site survey for the purpose of data verification. Section 4 provides the data findings and undertakes data analysis to identify factors that hinder the deployment of renewable energy. Section 5 offers conclusions and recommendations for better implementation of FIT policy in the future.

\section{A brief review of the feed-in-tariff policy}

\subsection{What is FIT policy?}

Historically, to spur the growth of renewable electricity, European countries set a price for electricity that is attractive to investors. This policy which was subsequently called feed-in-tariff (FIT) policy has three components: a fixed price which is sufficient for a return on investment, a guaranteed grid connection, and a long-term contract to ensure the stability of the investment (Mendonça 2007). By using this policy, investors do not have to deal with the cumbersome process of various incentives and tax exemptions, as applied in America (Farrel 2009: 6). This price is reviewed annually and it can be lowered if it attracts too many investors or creates windfall profit, and vice versa. Later on, this fixed price policy is accompanied by a mandate for utility companies to connect renewable electricity to the grid. In Europe, the cost of connection to the higher voltage is borne by the utility company, and the contract for selling electricity is short and uniform (Farrel 2009: 6).

According to IRENA (2012), there are four categories of deployment policies, namely: fiscal incentives, public finance, regulations, and access policies (Mitchell et al. 2011 in IRENA 2012). The FIT policy falls into the price-driven public finance policy category (IRENA 2012). 
Deployment, which is defined by IRENA (2012) as the stage of commercial roll-out, is a stage preceding full competition and maturity in the development of a new technology. In the commercial roll-out stage or deployment, economic support is needed to correct market failure and/or inadequate policy requirements. In the renewable energy market, failure comes from the discrepancy between the average production costs of electricity from fossil fuels or conventional energy and the production costs using renewables. Without consideration of the cost of research and development, externalities related to climate change, and other barriers to mass production, there is no way that renewable energy technology can compete with the energy price produced by conventional technology.

Another benefit of FIT policy implementation includes support for local ownership of renewable plants because of its simplicity, and thus it creates more jobs and increases the economic impact for the community. If we look at the experience of European countries, about half of wind turbines in Germany and about 80 per cent in Denmark are owned by local residents (Farrel 2009).

\section{Examples of FIT implementation}

The most notable success story of FIT policy is Germany's and Denmark's experiences in FIT implementation. Germany started to apply FIT policy in 1990, when the law required electricity utilities to connect renewable electricity to the grid and to buy the electricity at a price ranging from 65 per cent to 90 per cent of the average tariff for consumers (Mez 2012: 24). The implementation of FIT since then has spurred the expansion of wind turbine power plants in particular, from 20 MW in 1989 to more than 1,100 MW in 1995 (Lauber and Mez 2006 in Mez 2012: 24). In addition, Germany has also implemented a wind power programme and provides several kinds of subsidies and financial incentives for renewable energy investors. This policy, along with the implementation of the Renewable Energy Sources Act (RESA) in 2000, which was passed in order to achieve the targeted 25 per cent reduction of carbon-dioxide emissions, has resulted in an almost tenfold expansion in renewables from 1.3 per cent in 1990 to nearly 11 per cent in 2011 (Mez 2012: 26).

In 1988, Denmark applied a price policy for renewable electricity that paved a way for FIT policy, in which utility companies are required to set a fair price, purchase, and connect to the renewable electricity produced. This policy was successful in triggering the establishment of wind turbines, reaching $300 \mathrm{MW}$ of capacity. The FIT policy was formally applied in Denmark in 1993, when the purchase price of renewable electricity was set at 85 per cent of the average production and distribution cost and connection to the grid and purchase of power was guaranteed. This policy, along with an exemption for cooperatives from paying, has resulted in 28 per cent of Danish energy coming from renewables with wind turbines producing almost 3,000 MW of electricity. However, in 2004 the Danish ended the FIT policy and nowadays investors in renewable energy have to follow the renewable energy portfolio standard with tradable credits, such as applied in the USA (Farrel 2009).

\section{Barriers to FIT implementation}

Klein et al. (2010) warned that FIT policy should be kept transparent and not too complex, and their study evaluated the structure of electricity tariffs in several countries that could act as barriers to FIT implementation. In the USA, Farrel (2009) complains that the contract for electricity purchase can exceed 100 pages, while in Germany, for instance it is kept short to 4-5 pages. Another potential barrier is the condition of the electricity market, such as liberalization of electricity in New Zealand (White et al. 2013). 
However, another study in the European Union has suggested that the poor effectiveness of FIT policy is mainly caused by failure to tend to non-economic barriers, such as uncertain and lengthy administrative processes, and difficulties in gaining access to the grid (IRENA 2012: 13). Research by ECORYS (2008) into European Union member states, showed that there are some non-cost barriers that negatively impact the deployment of renewables to a different degree. One of the barriers most impacted is the administrative hurdles which include many issues, such as lack of coordination between institutions, length of time for obtaining authorization, the incoherence of procedures and regulations, big overhead costs, insufficient spatial planning, and social opposition. Other significant barriers are difficulty in getting grid connection and access, and limited information and awareness related to renewable energy among civil servants and the community in general (ECORYS 2008).

\subsection{FIT policy in Indonesia}

In Indonesia, a policy, which is similar to FIT, was issued in 2002 for small-scale hydropower plants. The MEMR issued a requirement for the SEC to buy electricity at 60 per cent of regional electricity production costs for low-voltage, and 80 per cent for middle-voltage connection. However, there have been some obstacles encountered in its implementation, one being the difficulty of determining the regional standard of production cost, and another being because energy production (especially of petroleum) was still heavily subsidized by the GOI, so that the utility company did not need to prioritize the use of renewable energy. The policy was improved in 2006 to include higher-scale hydropower plants (up to $10 \mathrm{MW}$ ), and then underwent some revisions in 2009 to include a more attractive tariff. Hasan and Wahjosudibyo (2014) argue that the obstacles to FIT implementation are mainly because there is no guarantee of long-term contracts and nor that the utility company will accept the contract.

A more formal kind of FIT policy was issued in 2011 and 2012, when the MEMR required the PLN to buy electricity from geothermal power plants at a fixed tariff of US $\$ 0.97 / \mathrm{kWh}$. Subsequently, the FIT for other renewable energy sources, such as solar and biomass, was issued in 2013 and 2014. In general, FIT regulation is targeted at reducing the time required for negotiating a price with the SEC (which, at times, can be several years), and making investment more attractive and long-term planning possible, thereby making RE investment viable. Table 1. shows the different FIT regulations for various RE sources, their original version, and the revisions. 
Table 1. Regulation of feed-in tariff in Indonesia for various RE sources

\begin{tabular}{|c|c|c|c|c|c|c|}
\hline \multirow[b]{2}{*}{ No } & \multirow{2}{*}{$\begin{array}{c}\text { RENEWABLE } \\
\text { ENERGY SOURCE }\end{array}$} & \multicolumn{4}{|c|}{ FEED-IN TARIFF REGULATION } & \multirow[b]{2}{*}{ NOTE } \\
\hline & & $\begin{array}{l}\text { Original } \\
\text { Version }\end{array}$ & $\begin{array}{c}\text { Electricity Price } \\
\text { (US\$/kWh) }\end{array}$ & $\begin{array}{l}\text { Revised } \\
\text { Version }\end{array}$ & $\begin{array}{c}\text { Electricity Price } \\
\text { (US\$/kWh) }\end{array}$ & \\
\hline \multirow{4}{*}{1} & \multirow{4}{*}{ Micro/ Mini Hydro } & \multirow{4}{*}{$\begin{array}{l}\text { MEMR } \\
\text { Regulation No. } \\
12 \text { year } 2014\end{array}$} & $<10 \mathrm{MW}=8$ cent & \multirow{2}{*}{\begin{tabular}{|l} 
MEMR \\
Regulation \\
No. 22 year \\
2014 \\
\end{tabular}} & $\begin{array}{l}<10 \mathrm{MW}=8 \\
\text { cent }\end{array}$ & $\begin{array}{l}7.2 \text { cent if using public } \\
\text { infrast i.e. irrigation }\end{array}$ \\
\hline & & & $\begin{array}{l}>250 \mathrm{kWh}=9.4 \\
\text { cent }\end{array}$ & & $\begin{array}{l}>250 \mathrm{kWh}=9.4 \\
\text { cent }\end{array}$ & $\begin{array}{l}8.4 \text { cent if using public } \\
\text { infrast i.e. irrigation }\end{array}$ \\
\hline & & & & \multirow{2}{*}{\begin{tabular}{|l} 
MEMR \\
Regulation \\
No. 19 year \\
2015 \\
\end{tabular}} & $\begin{array}{l}<10 \mathrm{MW}=12 \\
\text { cent }\end{array}$ & $\begin{array}{l}10.8 \text { cent if using public } \\
\text { infrast i.e. irrigation }\end{array}$ \\
\hline & & & & & $\begin{array}{l}>250 \mathrm{kWh}=14.4 \\
\text { cent }\end{array}$ & $\begin{array}{l}13 \text { cent if using public } \\
\text { infrast i.e. irrigation }\end{array}$ \\
\hline 2 & Geothermal & $\begin{array}{l}\text { MEMR } \\
\text { Regulation No. } \\
02 \text { year } 2011\end{array}$ & $\begin{array}{l}\text { on high volt. only } \\
9.7 \text { cent }\end{array}$ & \begin{tabular}{|l} 
MEMR \\
Regulation \\
No. 22 year \\
2012
\end{tabular} & \begin{tabular}{|l|} 
on high volt. \\
$10-17$ cent \\
on med. Volt. \\
$11.5-18.5$ cents
\end{tabular} & depend on location \\
\hline \multirow{6}{*}{3} & \multirow{2}{*}{ Biomass } & \multirow{6}{*}{$\begin{array}{l}\text { MEMR } \\
\text { Regulation No. } \\
\text { O4 year } 2012\end{array}$} & 9.75 cent & \multirow{4}{*}{$\begin{array}{l}\text { MEMR } \\
\text { Regulation } \\
\text { No. } 27 \text { year } \\
2014\end{array}$} & 8.5 cent & med volt. Interconn. \\
\hline & & & 13.5 cent & & 11.1 cent & low volt. Interconn. \\
\hline & \multirow{2}{*}{ Biogass } & & 9.75 cent & & 8.5 cent & med volt. Interconn. \\
\hline & & & 13.5 cent & & 10.4 cent & Iow volt. Interconn. \\
\hline & \multirow{2}{*}{ Municipal Waste } & & 10.5 cent & MEMR & 16.55 cent & high \& med volt. Intercn. \\
\hline & & & 13.98 cent & 44 year 2015 & $20.16 \mathrm{cent}$ & Iow volt. Interconn. \\
\hline \multirow{2}{*}{4} & \multirow{2}{*}{ SOLAR PV } & \multirow{2}{*}{\begin{tabular}{|l} 
MEMR \\
Regulation No. \\
17 year 2013
\end{tabular}} & up to 25 cent & & & local content $<40 \%$ \\
\hline & & & up to 30 cent & & & Local content $>40 \%$ \\
\hline
\end{tabular}

Note: Prices converted from rupiahs rely on its annual exchange rate.

Source: MEMR (2015).

It can be seen from the table above, that the GOI made several attempts to adjust and readjust the RE selling price; in some cases revisions were made more than once. In small hydropower plants, for instance, there were at least four MEMR regulations with different electricity prices which had been revised due to inputs from related parties, adjustment for inflation, and exchange rates. From the many revisions of FIT regulation, it can be concluded that the GOI puts in a lot of effort, and thus relies on this policy, to accelerate deployment of renewable energy.

\section{Data acquisition}

Effectiveness is defined as 'the extent to which intended objectives are met, for instance, the actual increase in the output of renewable electricity generated or shares of renewable energy in total energy supplies within a specified time period' (IRENA 2012: 12). In this study, the effectiveness of the FIT policy is measured by the increase in deployment of renewable energy power plants over the period since the policy was made in 2010 to date (a five-year period), compared with the GOI's target for achieving its share of the national energy mix. As suggested by IRENA (2012), in analysing the effectiveness of a policy, it is necessary to conduct an indepth analysis to elaborate factors that support or hinder the outcome of the policy, such as external factors or indirectly related barriers to the success of policy implementation.

\subsection{Study location}

Indonesia is made up of 17,000 islands and has one of the longest coastlines in the world. Most of the regions in Indonesia, especially in the eastern part, still have very poor infrastructure conditions. However, with a population of about 300 million and relatively stable economic 
growth (4-6 per cent per annum over the last five years), it is a country with many interesting prospects.

Politically speaking, Indonesia can be categorized as a country in transitional democracy, because, after its independence on 17 August 1945, democratic transition did not start to happen until 1998 when the long reign of General Suharto was toppled by students' demonstrations after thirty years of authoritative governance. After the so-called reformation era, Indonesian society has undergone a drastic change, including a shift from centralized to decentralized governance. Nowadays the people of Indonesia are enjoying a new sense of democracy. This new-found freedom allows them to freely question or even disobey what the government wants. This understanding of the political situation is important in comprehending the real condition of governance related to the deployment of renewable energy power plants.

This study uses a quantitative and qualitative research approach. The quantitative study is conducted by collecting, comparing, and analysing data from various institutions related to the targeted deployment of renewable energy power plants and its realization in the field. The comparison is followed by site visits to several locations for the purpose of confirmation. Due to limited time and budget, the confirmation field surveys were only conducted in West Java Province, a province adjacent to Jakarta, to gain a deeper perspective from players in renewable energy in real circumstances.

One reason for choosing West Java for site confirmation is because West Java is the province where the development of RE is considered to be the highest, and it has been a pioneer in RE development in Indonesia, such as in geothermal, micro-hydro, biogas, biofuel, etc. It is densely populated with about 46 million people inhabiting some 35,000 square kilometres of land. With 6.5 per cent annual economic growth in 2012, its energy consumption has continued increasing to around 8-11 per cent for all sectors, implying that the usage of energy is still inefficient. Thus, serious efforts to lower energy consumption, as well as efforts to diversify fossil-fuel energy with more renewable kinds of energy have been conducted since 2001. Some renewable energy technologies, such as micro-hydropower plants, are considered to be relatively successful. An index map for Indonesia and West Java Province is shown in Figure 1.

Figure 1. Index map of Indonesia and West Java Province

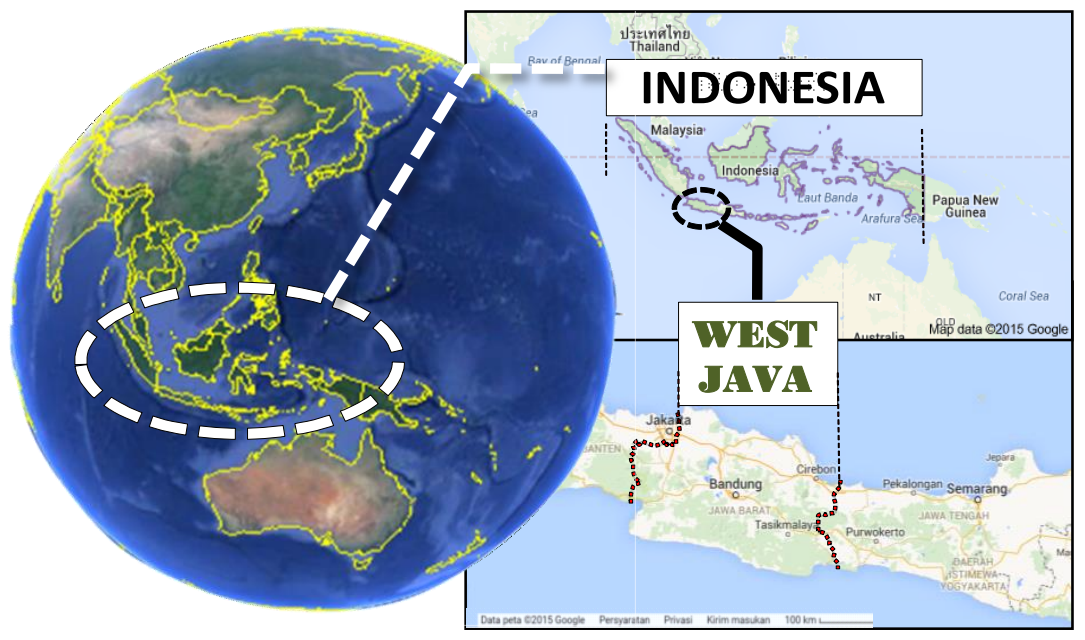

Source: Author's illustration from Google Earth-Maps 2015. 


\subsection{Quantitative data}

Data analysis from several data resources (MEMR, SEC, local government) resulted in a wide discrepancy between targeted installed capacity and its realization. Most commercial RE projects have been delayed by one to five years. As has been stated before, the comparison between projected and real data is only conducted for West Java Province, which is considered to mirror Indonesia's condition. As has been stated previously, the deployment of RE power plants includes the commercial operation of the plant, not just installation. The financial stage includes preparation of funding sources, negotiating and signing of a Power Purchasing Agreement (PPA) with the SEC, and the process of obtaining various kinds of permits (from central government as well as from local government). The construction stage includes land acquisition, community preparation, mobilization, and other construction activities. Figure 2 shows the actual installed capacity and the various stages of renewable energy power plant deployment from 2010 to 2015, or since the FIT implementation.

Figure 2. Deployment status of renewable energy power plants after FIT policy

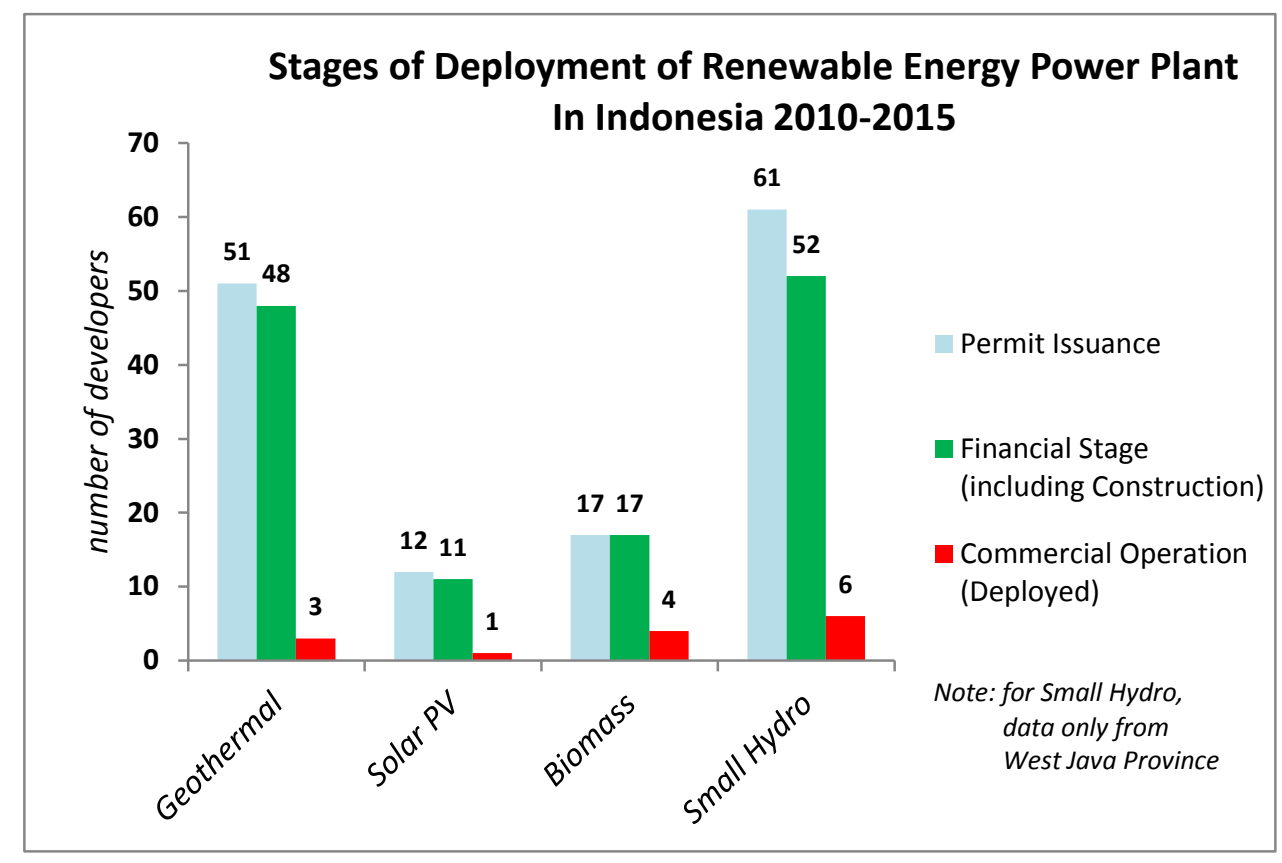

Source: Author's illustration from data compiled from various institutions and field surveys.

Official data issued by central government institutions are not consistent. For instance, for small hydropower, one published report says that there are only 19 small hydropower licences in West Java, while another institution states there are 31, and yet another says 34 licences. When these data are cross-checked with data from local government (regency), the compilation from regencies which have small hydropower sites suggests there are 61 small hydropower licences in West Java.

Another interesting result of the data analysis is that, on average, only 10 per cent of permits issued for power generation from the renewable energy source, are already at the commercial operation stage or deployed. Some of the permits had been issued for more than five years. Thus, there must be some problems in the field that prevent the FIT policy from having a positive effect on the deployment of renewable energy power plants. To delve deeper into this discrepancy, qualitative surveys were conducted using semi-structured interviews. The identities of all those interviewed in this study, including experts, developers, and public authorities, are confidential due to the sensitivity of the issue. 


\subsection{Qualitative data}

From the collected data and results of the analysis, an attempt to elaborate the causes of the discrepancy between projected goals and the real situation is conducted using semi-structured interviews. It is worth noting that not everyone contacted who was directly involved in the deployment of RE was willing to be interviewed, especially government officials and developers. Some were eventually willing to give information when the interview was conducted outside of their offices, some objected to the interview being recorded, and most of them agreed to be interviewed with the promise that their names would not be revealed. On average, the interviews lasted between about 15 minutes and 2 hours; some were recorded while others were field-noted.

In total, there were 22 key respondents, consisting of 5 investors (4 small hydropower developers and 1 geothermal), 14 government officials ( 5 from central government, 2 from provincial government, and 7 from regency (local) government), and 3 respondents from related agencies (1 SEC, 1 expert, 1 practitioner). Respondents were asked to answer the following questions:

Table 2: List of guidance questions for key respondents

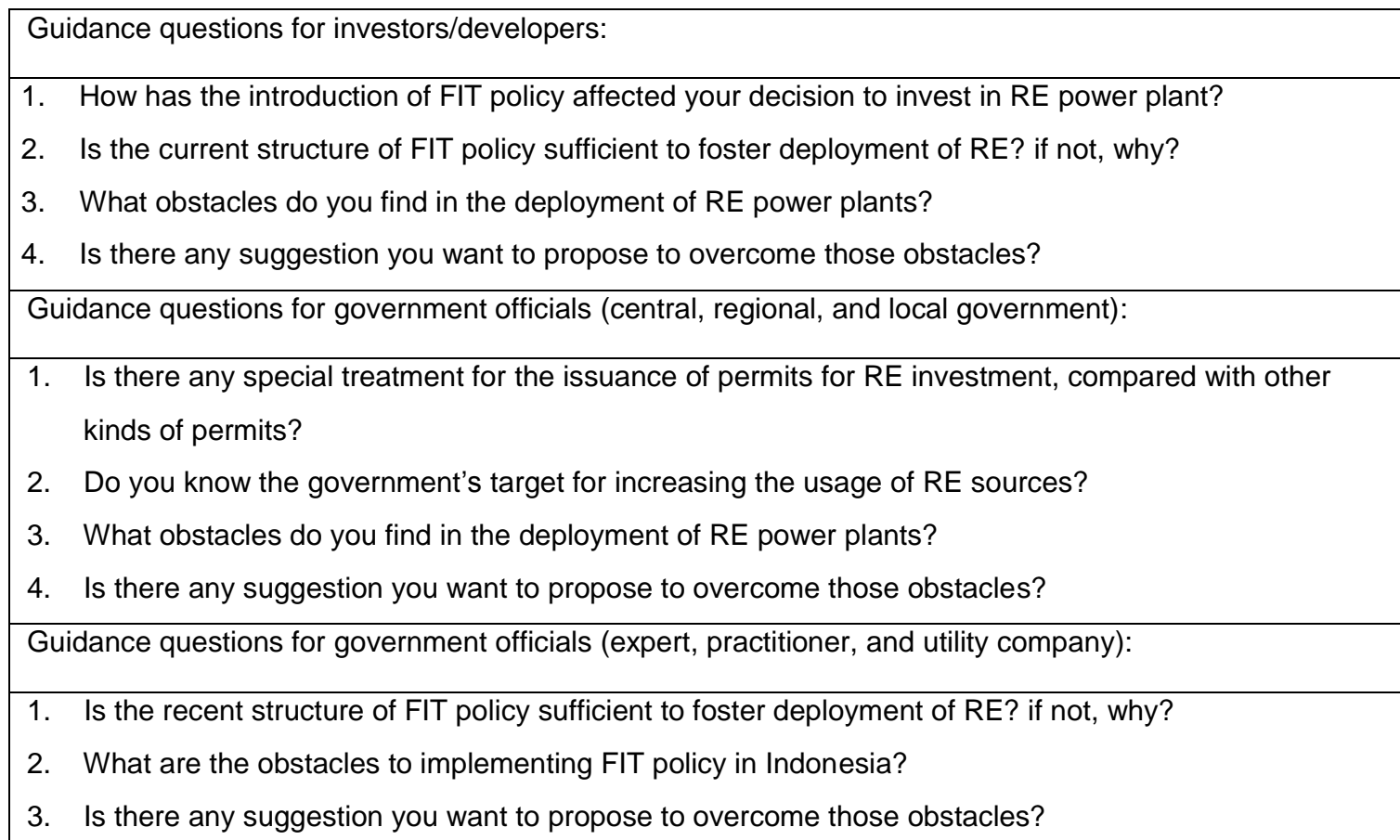

Source: Author's illustration.

The analysis is focused on the evaluation of FIT policy in Indonesia: whether it is effective in increasing the usage of RE, whether there is any room for improvement, and if not effective, then what are the alternatives. For definition purposes, deployment of renewable energy means the power plant is not just already installed and producing electricity, but it also has generated income from selling electricity.

\section{$4 \quad$ Analysis}

\subsection{Effectiveness of FIT policy}

It is interesting to note, that since around 2011 when the FIT policy was first made, investment in renewable energy has been increasing significantly. However, the study results showed a totally 
different outcome regarding real deployment of renewable energy power plants. Take geothermal energy, for instance: from 51 licences issued by the MEMR, only 3 are operational commercially in 2015. This means that the amount of delayed deployment of geothermal power plants exceeds 90 per cent. For solar PV and biomass, data for real deployment of power plants are not very different. For small hydropower plants, the data, which are taken only from West Java Province, show that the rate of successful deployment is no better, with only 6 out of 61 licences having been fully deployed commercially.

Those at the construction phase (representing a total 56.69 MW from nine companies) report that the delayed construction stage is mostly caused by difficulties in obtaining a location permit or a building permit from local (regency) government, hard negotiations of land price, and the demands of local communities. In West Java, there are no biomass (domestic waste to energy power plant), solar PV, or wind turbine power plants which are fully operational in a commercial sense. Some small MWs have been installed (solar PV and biomass), but negotiations of price and other related processes are still underway.

The 19 small hydropowers that are in the finance phase (total 88,174 MW) report several problems including difficulties in obtaining PPA with the SEC and the long process of permit issuance for surface water usage, in which the two processes are intermingled. It is interesting that policies for river usage permits, which depend on where the river is located, are different from one locality to another, and from local government to central government (the Ministry of Public Works).

One unique example is a small hydropower plant of $600 \mathrm{~kW}$ in a region of Central Java Province, which has been fully constructed but has not been operational because it has not obtained the PPA from the SEC. And the SEC cannot issue the PPA because the related institution has not been issued with a permit for water resource utilization. There has been much confusion over who is authorized to issue the permit: initially it was thought to be the responsibility of local government, but, then it was clear that the specific watershed's authority belongs to central government (Ministry of Public Works). However, up until now the permit has not been issued by the Minister, with no clear explanation.

When asked whether the structure of FIT policy has met their expectations, all respondents from investors of RE power plants admitted that the structure and the selling price have been sufficient to make the project (on paper) seem viable, and this has greatly affected their decision to invest in renewable energy. Especially for small hydropower investors, who enjoy a high price of electricity and for whom the domestic content of the technology is relatively high, the structure of small hydropower has caused a surge of domestic investors who are interested in investing. This attractiveness of RE investment has been confirmed by the US Department of Commerce report (2010) and the UNDP report (2015). However, the investors convey that, in the process of development, the many additional costs incurred by the many kinds of permits that have to be obtained before they are fully operational, and the long delays caused by them, have eroded the profitability of RE projects.

\subsection{Procedure for obtaining a renewable energy licence}

In delving deeper into the permit procedure, the research is focused on small hydro development in West Java Province only, due to limited time and budget. As has been stated previously, there is no coherent data between institutions and no transparency of information. At the lower level of government, which is provincial and regency government, this is even worse. That is why, interviews were conducted covertly, and some of those interviewed agreed to be interviewed only on condition that their names would not be revealed. Figure 3 displays the general 
procedure to be conducted in order to obtain a small hydropower plant licence. The flows of procedures at the lower levels of government (province and regency government) are simplified and compiled from practices existing in different regencies.

Figure 3: Procedure for the issuance of licences for small hydropower generation.

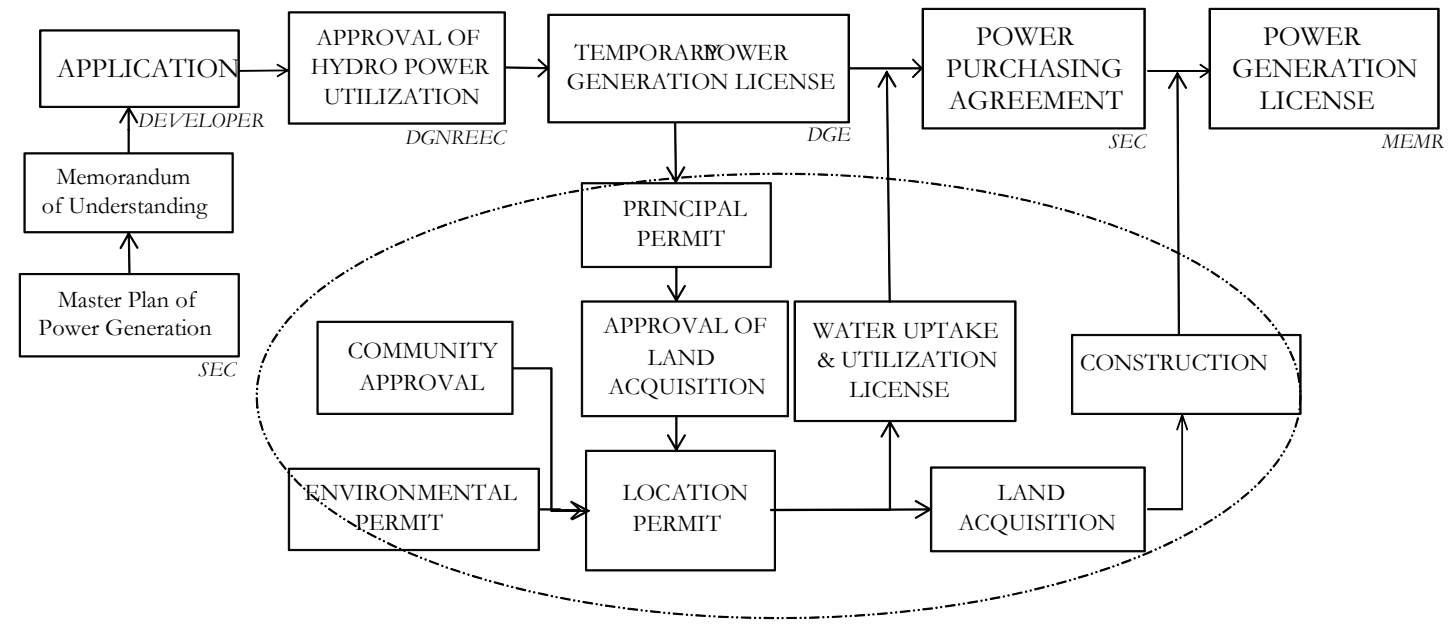

Note: Processes at local government level.

Source: Author's illustration.

The upper part of the procedure illustrates the flow of applications for power plant licences according to MEMR Regulations No 22/2010, where the developers of on-grid power generation must submit an application to the Directorate General of Electricity and must previously have had a memorandum of understanding with the SEC that the planned location of the development is already included in the Master Plan. Then, the developer must submit a deposit of 5 per cent of total investment to the Directorate General of New and Renewable Energy, in order to obtain Approval for Hydro Utilization. Thereafter, a temporary permit for small hydropower generation is issued. Based on this temporary permit, the developer must then go through the procedure at the lower level of government (province government and related regency government).

This is where matters get more complicated, because, in order to conduct land acquisition, the developer must go through several processes, often very tiring, with no time limit, and a lot of additional (and unofficial) cost. To make matters worse, there is no standard procedure for this land acquisition between regencies, and the process may vary greatly from one place to another. When there is forest land included in the design, the matter is even more complicated because the timeline of the procedure to obtain permission to use the land often exceeds the length of the permit.

In general, there are at least 14 kinds of licences and permits (and other permit-like processes) that have to be obtained before a developer can start the construction of a RE power plant: four from central government, one from provincial government, and nine from regency government. There are also some associated recommendations from related bodies which are a must-have requirement before a permit can be issued (this includes community approval). For geothermal investment, this number may well be higher, especially for foreign investors. It is worth noting that the costs associated with permit issuance are generally not stated clearly; sometimes they need to be negotiated, and sometimes they require much higher costs than expected. Although some RE investors admit that they have prepared for such excess costs, nevertheless the 
negotiation process requires time, delays schedules, and lowers the profitability of RE investments.

\subsection{Obstacles to deployment of renewable energy}

\section{Incoherent regulations between related institutions}

Incoherent knowledge about renewable energy, different agendas, and overlapping policies between ministries and moreover between central government and local government, surfaced several times in the elaboration of obstacles to renewable energy deployment. One provincial government official who was authorized to issue water utilization permits complained that the MEMR issued a permit to build small hydropower without stating the exact location, with the result that local government, in certain areas of West Java, issued two permits for one exact same location. This disturbs the steady flow of the river and potentially could conflict with rice field irrigation. He then questioned whether the river discharge usage permit should come before or after a small hydropower plant permit is issued by the MEMR. However, when questioned about this problem, the regency government official seemed not to recognize this problem, stating that they only process location permits as they are proposed, and that there is no clarification process with the higher level of government or with related institutions whatsoever. Thus, if there is overlapping of location permits, it is not their problem.

The institutional problem becomes worse when an RE power plant is to be built in a conservation or protected forest area because the clearance and permit to use the forest area must come from the Minister of Forestry. Even though they know that renewable energy plants would not damage the forest (unlike mining, for instance), still there is no special treatment for the so-called sustainable energy and non-sustainable usage of the forest. Even though, recently, there has been a revision for geothermal energy that enables protected forest to be used for geothermal power plants, a geothermal investor respondent still complained that the issuance of the permit is long and complex.

\section{Long process of electricity purchasing}

Investors also convey that the signing of a PPA with the SEC is extremely complex and technical and bargaining is tough. Sometimes the process took longer than a year. A geothermal power plant investor stated that he has to wait four years before the agreement is reached. Another investor even suspects that the SEC is reluctant to buy electricity from renewable energy sources because it then has to cover additional costs compared to when it uses coal-fired power plants (personal interviews, August to September 2015).

Meanwhile, in reply to questions about the many difficulties experienced in obtaining PPAs, the Director of Business Ventures of the SEC (personal interview, September 2015) denied that the SEC is reluctant to buy electricity from RE sources, stating that it is mandatory for the SEC to buy in accordance with the MEMR regulations. However, as a state-owned company, there are several requirements that have to be met before issuance of a PPA including, among others, obtaining all related permits, land clearance, and agreement with the local community. In reply to questions about the profitability of trading electricity from RE sources, she admitted that the price is considerably higher than coal generated electricity (average production cost of around US\$0.5). At present, the buying price of electricity from RE varies between US $\$ 0.10$ and US $\$ 0.17$, which is sold to the public at an average price of around US $\$ 0.8$ to US $\$ 0.9$, and this makes the discrepancy in cost a burden for the SEC to cover from elsewhere. 
Another complaint from the SEC is that while they have to pay instantly the electricity price as generated, reimbursement from the government is dependent on the national budgeting agenda. Reimbursement is sometimes delayed for several months and sometimes is not provided at the exact amount that has been disbursed by the SEC. Thus, she proposed that there should be an independent agency to manage the financing of electricity from RE sources which deal with the electricity price negotiations, payments of power purchasing, and all related matters. Learning from the case of Malaysia and Thailand, this agency would ensure that the discrepancy in cost between the average production cost and the selling price from conventional power plants, which is reimbursed in the form of government subsidy, can be managed effectively without depending on political processes in the annual national budgeting agenda.

\section{Problems with community and land acquisition}

Another factor that hinders speedy deployment of RE power plants is that in some locations the community does not wish to sell its land due to lack of knowledge about renewable energy. This is especially true for geothermal energy, where in West Java at least, there are four locations where geothermal plants are delayed due to various kinds of conflict. Yuliani (2013) stated that community resistance in many locations of geothermal development in Indonesia represents the major obstacle to renewable energy deployment. Similarly, Hasan and Wahjoesudibjo (2014) suspected that there are several issues other than the electricity tariff that have to be addressed by the government in order to improve geothermal power plants.

It is worth noting that, after some 30 years of relatively authoritarian governance, since around the 2000s, the Indonesian people have been enjoying a more democratic atmosphere in what is called the reformation era, where governance is more decentralized, public policy is more bottom-up and participatory, and there is a new-found freedom of speech among the people. Yuliani (2013) noted, that this new condition in a community sometimes brings problems for the development of infrastructure, especially when there is no sufficient preparation for the community to accept new things, such as renewable energy technology. Even respondents from local government officials (regency government) show that this lack of information is not only true for the layman but also for bureaucrats.

In the deployment of small hydropower plants, community conflicts are usually about the amount of water used for irrigation, which mostly can be solved by good communication. However, unavailability of a standard price for land, especially in remote areas, often delays the land acquisition process and if the price wanted by the community exceeds the expected figure this can lower the economic viability of the project. It is worth noting that, for the foreign investor, this problem of the price of land skyrocketing may worsen, and needs to be carefully considered.

\subsection{Miscellaneous: unanticipated impacts of FIT policy}

The significant increase in renewable energy investment, especially for small hydropower, creates several unanticipated impacts which are not always positive. Government officials, as well as developers, report that there is some kind of rivalry between institutions related to the importance of their role in permit processes. The struggle to acquire the most profitable sites for hydropower plants has created a situation where power plants are located very near each other. On the supply side, it is a worrying situation, because there is no capacity cap that limits how much of the generated electricity the electricity company is willing to buy.

Related to land acquisition, a growing number of people play the role of a land realtor, hoping that they can benefit from discrepancies in land prices. This, in turn, makes the price of land 
uncontrollable in some regions. One developer complained that government officials are also players in land acquisition deals.

Before the implementation of FIT, small hydropower was used to electrify communities in remote regions, usually with aid from the government. However, with the massive emergence of hydro investors and the fight for the best locations, these community-based small hydropower plants are left behind. In West Java, there are at least two locations where micro-hydro plants were ready to be constructed but eventually failed because the power plant licence for the exact location had been issued by the MEMR.

\section{$5 \quad$ Conclusion and recommendations}

\subsection{Conclusion}

Indonesia is an example of a country where FIT policy, which is considered quite successful in developed countries, is duplicated without careful considerations of the existing socio-political conditions. The FIT policy in Indonesia, which has been formulated in eight ministry regulations (four original versions and five revised versions) has not significantly improved deployment of its renewable energy. It is true that investment interest in renewable energy has soared to a level which has never been seen since its implementation around the 2010s. However, data confirmed through field reports shows that about 90 per cent of scheduled deployments of renewable energy power plants are delayed, and targets are far from realized.

Many complaints related to difficulties in obtaining a PPA, lack of a guarantee of grid connection, and complex contract structure, indicating that some of the FIT policy principles are not being met, although the price of electricity is satisfactory. The study also reveals several other issues that pose obstacles to renewable energy deployment, which can be grouped into three big problems: unclear and inconsistent policies both horizontally (between ministries) and vertically (between levels of government), the complex requirements of many permits, and difficulties related to land acquisition which includes conflict with the community. Adding to those problems in the field is the corrupt behaviour in permit issuance processes, which has made the calculation of the economic scale of a project difficult.

To sum up, the FIT policy when applied in a less developed country such as Indonesia, must work in tandem with other efforts. The complex structure of governance, lack of community knowledge about renewable energy, and incoherent coordination between related institutions, all add up to difficulties of implementation in the field. If Indonesia is serious about achieving its projected goals for renewable energy deployment, then efforts must be strengthened and calculated measures must be taken. On the other hand, the study also underlines the importance of narrowing the wide gap in transitioning to cleaner energy, where less developed and developed countries both face very different challenges.

\subsection{Recommendation}

In order to enhance the effectiveness of FIT policy in increasing the success of renewable energy deployment, it is recommended that the GOI simplifies the licence procedures, either at the central government level or most especially at the local government level. This will require an exceptionally strong commitment from all parties, because every institution holds to its own laws and regulations, and may not have the same agenda for the development of renewable energy. 
The existence of specific budgets allocated for renewable energy subsidies, as implemented by many countries, can play a significant role in lessening the burden of developers. The subsidy which is intended to pay for the discrepancy of production costs between renewable energy and conventional power plants has to be independently managed, and not be dependent on the political process in the national budget planning which is decided annually. One realistic option is to form an independent body which is given the mandate to facilitate the permit process, formulate and finalize PPA, and manage various aspects related to pricing and payments of the government subsidy for renewable energy.

It is also recommended that the GOI should not abandon community-based efforts in renewable energy deployment. The excessive focus on investment to boost renewable energy deployment is not sustainable because it does not create a sense of belonging from the surrounding community. On the other hand, there is a lot of under-utilized renewable energy potential which is most suitable to be used for domestic energy, such as biomass.

\subsection{Suggestions for further research}

Due to the limited time and budget for conducting this field survey, in-depth investigation of locations for the deployment of renewable energy power plants has only been conducted at a limited number of sites. It is suggested that a thorough assessment is conducted in other parts of Indonesia, including of all kinds of renewable technologies. Field practices at the lower level of government may vary from place to place. Thus, a comparison between regions is recommended in order to obtain a general description of how permit procedures are carried out at local government level, and eventually, to suggest the best option for simplifying procedures and increasing the effectiveness of deployment. There are at least two small hydropower plants which are said to have been operational in published reports by related institutions; in reality, they are still in the process of becoming fully operational commercially. Thus, it is best to check the location of development on the site to assess the real situation, especially for solar PV and biomass power plants which are located in remote areas of Indonesia.

The availability of low-interest loans dedicated to renewable energy development from various banking and financial institution, both national and international, must also be scrutinized. The fact that about 90 per cent of power plant licences have not shown any progress after several years, raised some concerns about prejudice from several of those surveyed that the licences are used to obtain loans to be invested elsewhere. In this study, the researcher does not have access to any banking personnel and, under the bank privacy principle, it could be difficult to get any information. However, in order to create a healthy investment climate for renewable energy, it is suggested that measures are taken to ensure that renewable energy loans are used appropriately.

\section{References:}

DGNREEC (2014). Unpublished Presentation 'Role and Strategy for Development of Renewable Energy and Energy Conservation'.

DGNREEC (Direktorat Jenderal Energi Baru Terbarukan dan Konservasi Energi) (2015). 'Statistik EBTKE 2015'. Jakarta: DGNREEC. Available at: http://www.ebtke.esdm.go.id/ (accessed on 30 September 2015).

ECORYS (2008). 'Assessment of Non-Cost Barriers to Renewable Energy Growth in EU Member States-AEON'. DG TREN No. TREN/D1/48 - 2008. Rotterdam: ECORYS. Available https://ec.europa.eu/energy/sites/ener/files/documents/2010_non_cost_barriers.pdf (accessed on 19 February 2016). 
Farrel, J. (2009). 'Feed-in tariffs in America: Driving the Economy with Renewable Energy Policy that Works'. Minneapolis. Available at: http://ilsr.org/wpcontent/uploads/files/feed-in\%20tariffs\%20in\%20america.pdf (accessed 1 March 2016).

Government of Indonesia (2014). 'Government Regulation No.79/2014 on National Energy Policy'. Available

http://prokum.esdm.go.id/pp/2014/PP\%20Nomor\%2079\%202014.pdf (accessed on 30 September 2015).

Hasan, M., and A.S. Wahjosudibjo (2014). 'Feed-In Tariff for Indonesia's Geothermal Energy Development, Current Status and Challenges'. Proceedings of Thirty-Ninth Workshop on Geothermal Reservoir Engineering Stanford University. Stanford, California, February 24262014.

IRENA (International Renewable Energy Agency) (2012). 'Evaluating Policies in Support of the Deployment of Renewable Power'. Available at: http://www.irena.org/menu/index.aspx?mnu=Subcat\&PriMenuID=36\&CatID $=141 \&$ Sub catID $=251$ (accessed on 19 September 2014).

Klein, A., E. Merkel, B. Pfluger, A. Held, M. Ragwitz, G. Resch, and S. Busch (2010). 'Evaluation of Different Feed-in-Tariff Design Options-Best Practice Paper for the International Feed-In Cooperation'. ${ }^{\text {rd }}$ Edition. A joint research project between Energy Economics Group (EEG) and Fraunhofer ISI. Available at: file:///C:/Users/George/Downloads/Best_practice_Paper_3rd_edition.pdf (accessed on 1 March 2016).

Lauber, V., L. Mez (2006). 'Renewable Electricity Policy in Germany, 1974 to 2005'. Bulletin of Science, Technology \& Society, 26(2): 105-120.

MEMR (Ministry of Energy and Mineral Resources) (2015). Road Map for Accelerated Development of New and Renewable Energy 2015-2025. Jakarta: MEMR.

Mendonça (2007). Feed-in Tariffs: Accelerating the Deployment of Renewable Energy. London: Earth Scan.

Mitchell, C., et al. (2011). 'Policy, Financing and Implementation'. In IPCC Special Report on Renewable Energy Sources and Climate Change Mitigation. Cambridge and New York: Cambridge University Press, pp. 865-950.

Mez, L. (2012). 'Germany's Merger of Energy and Climate Change Policy'. Bulletin of the Atomic Scientists, 68(6): 22-29.

UNDP (2015). The State of Indonesia's Renewable Energy. Available at: http://www.id.undp.org/content/indonesia/en/home/presscenter/articles/2015/07/22/t he-state-of-indonesia-s-renewable-energy.html (accessed on 30 September 2015).

US Department of Commerce (2010). Renewable Energy Market Assessment Report: Indonesia. Available http://www.iea.org/publications/freepublications/publication/indonesia2008.pdf (accessed on 30 September 2015).

White, L.V., B. Lloyed, and S.J. Wakes (2013). 'Are Feed-in Tariffs Suitable for Promoting Solar PV in New Zealand Cities?'. Energy Policy, 60: 167-78. http:/ / dx.doi.org/10.1016/j.enpol.2013.04.079 (accessed on 16 April 2015)

Yuliani, D. (2013). 'Dynamics of Community Resistance in Planning (Case Study: Development of Geothermal Power Plant in Mount Tampomas, Sumedang, Indonesia)'. Unpublished Dissertation, Institute of Technology of Bandung, Indonesia. 